\title{
Insulin Receptors in Cultured Mouse Retinal Cells
}

\author{
P. Thomopoulos ${ }^{1}$ and B. Pessac ${ }^{2}$ \\ ${ }^{1}$ U-35, I.N.S.E.R.M., Hôpital Henri Mondor, Créteil, and 2 U-178, I.N.S.E.R.M., Hôpital Broussais, Paris, France
}

\begin{abstract}
Summary. The binding of ${ }^{125} \mathrm{I}$-insulin to uncloned and cloned cultures of mouse retinal cells has been investigated. At $15^{\circ} \mathrm{C}$, binding of the hormone reached a steady state by $60 \mathrm{~min}$, while at $37^{\circ} \mathrm{C}$ equilibrium was reached earlier but at a lower level than at $15^{\circ} \mathrm{C}$. Porcine insulin, porcine proinsulin and guinea pig insulin displaced labelled insulin in proportion to their known biological potency. A sharp $\mathrm{pH}$ dependence of the hormone binding was observed with an optimum at $\mathrm{pH} 7.8$. The dissociation rate of the ${ }^{125} \mathrm{I}$-insulin was increased in the presence of unlabelled hormone, suggesting the existence of negative cooperativity in the insulin-receptor interaction. The availability of established retinal cell lines with insulin receptors should facilitate the study of the insulin-retina interactions in a controlled in vitro system.
\end{abstract}

Key words: Insulin, receptors, mouse embryo retina, Simian virus 40, established cell lines.

Insulin may exert indirect effects on the central nervous system by modulating the plasma levels of precursors of neurotransmitters [1] and of glucose. In addition, evidence has accumulated to support a direct action of insulin on cells of the central nervous system and to indicate that this hormone may regulate their function $[2,3,4,5]$. Specific binding of ${ }^{125} \mathrm{I}$-insulin to membrane preparations of whole brain of rat, monkey and pigeon [6] has been reported and recently the regional distribution of insulin receptors in the central nervous system of the rat has been investigated [7].

The intact isolated retina, as well as dissociated retinal cells in short term cultures, have been exten- sively used for the study of neuronal metabolism [8, 9, 10,11]. The mixed cell population of such preparations however, is an obvious disadvantage and does not allow examination of specific cell types.

This problem might be solved by two recent reports. First, cell proliferation has been induced in chick embryo neuroretina cultures transformed by Rous Sarcoma virus [12] and second, mouse embryo retina cells transformed by Simian virus 40 have been described [13]. The latter system permits separation of the mixed cell population into permanent clones.

The present work reports the characterisation of the insulin receptors in these mouse retina cell cultures [13] and in some of the clones derived from them.

\section{Materials and Methods}

Monocomponent porcine insulin, porcine proinsulin, guinea pig insulin and porcine glucagon were purchased from Novo Research Inst., Copenhagen, Denmark. Synthetic 1-24 adrenocorticotrophin was from Ciba-Geigy, Basel, Switzerland. Sodium ${ }^{125} \mathrm{I}$ (carrier free) was from The Radiochemical Centre, Amersham, Bucks, U. K., and bovine serum albumin (fraction V) and HEPES (N-2-hydroxyethyl piperazine - N'-2-ethanesulphonic acid) from Sigma, Saint Louis, Mo., U.S.A. All other chemicals were from Merck, Darmstadt, West Germany.

The retinal cells were established and maintained in culture as previously described [13]. Cloning of the mixed cell cultures was performed by diluting the suspended cells and plating them in tissue-culture clusters containing 96 wells $(6.4 \mathrm{~mm}$ diameter each) from Costar, Cambridge, Mass. U.S.A. In order to minimise the possibility of plating two cells together, the calculated plating density was of one cell per three culture wells. The cloning procedure was repeated twice, after the first clones were obtained. ${ }^{125} \mathbf{I}$ insulin was prepared at specific activities of $150-200 \mu \mathrm{Ci}$ per $\mu \mathrm{g}$ (approximately 0.5 atoms of iodine per insulin molecule) by a chloramine T iodination method [14]. For binding studies, the cells were detached from the dishes, when the cultures were subconfluent, by incubating them with $5 \mathrm{ml}$ of $\mathrm{Ca}^{++}, \mathrm{Mg}^{++}$-free Dulbecco's PBS (pH 7.4) containing $1 \mathrm{mMol} / 1$ disodium EDTA, at $37^{\circ} \mathrm{C}$. 


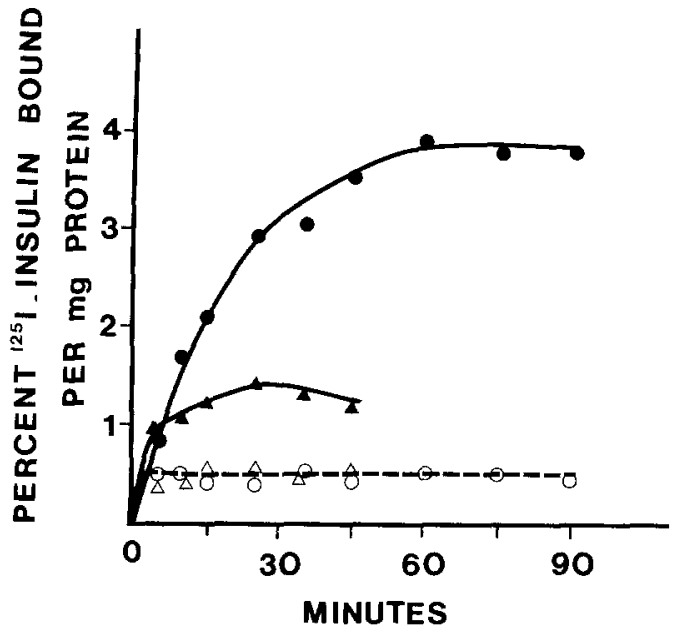

Fig. 1. Time course of ${ }^{125}$ I-insulin binding to retinal cells. The cells were removed from the Plates as described in Methods and were incubated with ${ }^{125}$ I-insulin $\left(2 \times 10^{-11} \mathrm{~mol} / \mathrm{l}\right)$ in the absence (closed symbols) or presence (open symbols) of unlabelled insulin $\left(1.7 \times 10^{-6} \mathrm{~mol} / \mathrm{l}\right)$. The experiments were performed at $15^{\circ} \mathrm{C}$ (circles) or at $37^{\circ} \mathrm{C}$ (triangles). Each point is the mean of triplicate determinations. The results shown are taken from one experiment considered typical of a series of four. The cell concentration was 3 $\times 10^{6}$ cells $/ \mathrm{ml}(1 \mathrm{mg}$ cell protein $/ \mathrm{ml})$

After incubation for $15 \mathrm{~min}$ the cells were detached by gently pipetting the medium over the monolayer 5-10 times. The cells were then sedimented by centrifugation for $5 \mathrm{~min}$ at $250 \mathrm{~g}$ and resuspended in the binding buffer (see below). They were centrifuged again at $250 \mathrm{~g}$ and resuspended in the same buffer.

The assays for measuring ${ }^{125}$ I-insulin binding have been described previously [15]: the cells were incubated in a buffer containing $0.1 \mathrm{~mol} / 1$ HEPES, $120 \mathrm{mMol} / 1 \mathrm{NaCl}, 1.2 \mathrm{mMol} / 1$ $\mathrm{MgSO}_{4}, 5 \mathrm{mMol} / 1 \mathrm{KCl}, 15 \mathrm{mMol} / 1 \mathrm{Na}$ acetate, $10 \mathrm{mMol} / 1$ glucose, $1 \mathrm{mMol} / 1$ disodium EDTA and $1 \mathrm{~g} / 100 \mathrm{ml}$ bovine serum albumin at $\mathrm{pH} 7.8$, to an approximate cell concentration of 2.5 to $4 \times 10^{6}$ cells $/ \mathrm{ml}$. The incubation temperature was $15^{\circ} \mathrm{C}$ to minimise insulin degradation [16]. Separation of free and bound hormone was achieved by centrifugation in a Beckman microfuge [15]. "Total" binding corresponded to the radioactivity in the cell pellet, and "non specific" binding to the radioactivity bound to the cells in the presence of $1.7 \times 10^{-6} \mathrm{~mol} / \mathrm{l}$ unlabelled insulin. The results are expressed as the percent ${ }^{125}$ I-insulin bound either per mg of total cell protein (in the uncloned cell cultures) or per $10^{6}$ cells (in the cloned cell lines). Possible degradation of the unbound labelled insulin (i. e. in the cell-free supernatant) was assessed by measuring its ability to bind at $4^{\circ} \mathrm{C}$ to insulin receptors of purified rat liver membranes prepared according to Neville [17] as described by Feychet et al. [16]. Cell viability was determined at the conclusion of each experiment by the trypan blue exclusion method [18]. In all experiments, $90 \%$ or more of the cells excluded the dye. Protein was assayed by the method of Lowry [19] using bovine serum albumin as standard.

\section{Results}

The properties of the insulin receptor in the uncloned cultures of the established mouse retina cells were investigated first. The "specific" binding of the hor-

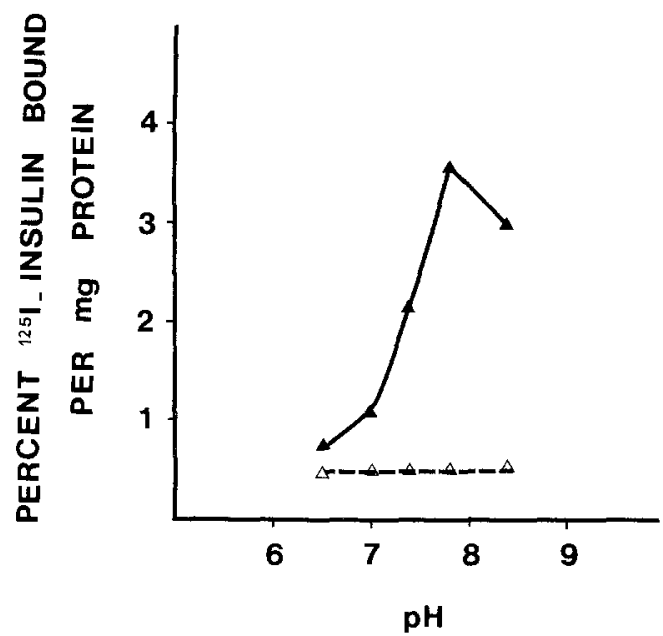

Fig. 2. pH dependence of ${ }^{125} \mathrm{I}$-insulin binding to retinal cells. The cells were incubated for $60 \mathrm{~min}$ at $15^{\circ} \mathrm{C}$ with ${ }^{125} \mathrm{I}$-insulin $(2 \times$ $10^{-11} \mathrm{~mol} / \mathrm{l}$ ) in the absence (closed triangles) or presence (open triangles) of unlabelled insulin $\left(1.7 \times 10^{-6} \mathrm{~mol} / \mathrm{l}\right)$. Each point is the mean of triplicate determinations. The results shown are taken from one experiment considered typical of a series of two. The cell concentration was of $3 \times 10^{6}$ cells $/ \mathrm{ml}(1 \mathrm{mg}$ cell protein $/ \mathrm{ml})$

mone was time-dependent, reaching a steady state by $60 \mathrm{~min}$ at $15^{\circ} \mathrm{C}$ and remaining at a constant level for $120 \mathrm{~min}$. At $37^{\circ} \mathrm{C}$ the amount of tracer "specifically" bound was lower, but the steady state was reached earlier than at $15^{\circ} \mathrm{C}$ (Fig. 1). The binding showed a sharp $\mathrm{pH}$ dependence with an optimum at $\mathrm{pH} 7.8$ (Fig. 2). The specificity of the insulin receptor has been characterised by the inhibition of ${ }^{125} \mathrm{I}$-insulin binding effected by unlabelled insulins of known biological potencies. Thus, in the uncloned cultured retinal cells, porcine insulin was 15 times more potent than porcine proinsulin and 20 times more potent than guinea pig insulin in inhibiting ${ }^{125} \mathrm{I}$-insulin binding; unrelated peptide hormones (porcine glucagon, synthetic 1-24 adrenocorticotropin) were unreactive at $2 \times 10^{-7} \mathrm{~mol} / \mathrm{l}$ (Fig. 3).

The degradation of the unbound labelled insulin was negligible in all experiments performed at $15^{\circ} \mathrm{C}$. Up to $30 \%$ of the hormone was degraded however at $60 \mathrm{~min}$ when the incubation temperature was $37^{\circ} \mathrm{C}$ (results not shown).

When the binding data at equilibrium were analysed according to Scatchard [20], a curvilinear plot was obtained (Fig. 4). This phenomenon has been studied in detail by De Meyts et al. [21, 22] who provided experimental and theoretical evidence that it may be explained by site-site interactions of the negative cooperative type of the insulin receptor. Using the method reported by these authors, we were able to show that the dissociation rate is increased in 


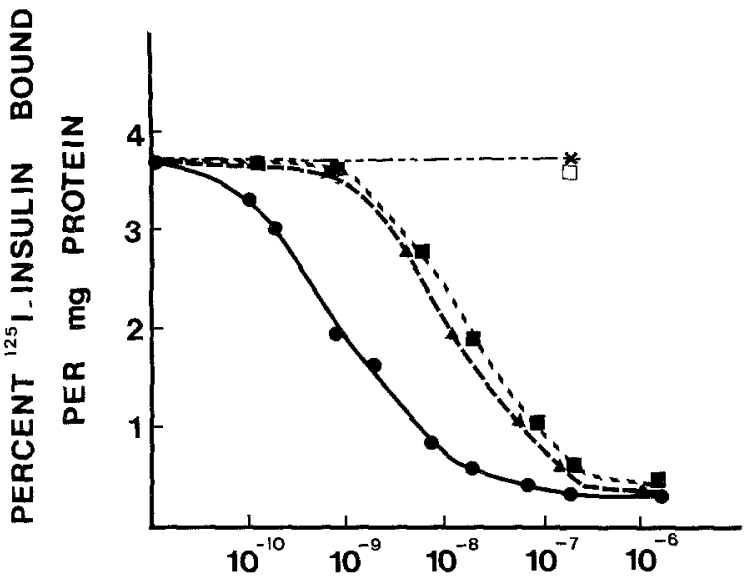

HORMONE CONCENTRATION (mol $/ \mathrm{l})$

Fig. 3. Competition of ${ }^{125} \mathrm{I}$-insulin binding by unlabelled hormones. The cells were incubated for $60 \mathrm{~min}$ at $15^{\circ} \mathrm{C}$ with ${ }^{125}$ I-insulin $\left(2 \times 10^{-11} \mathrm{~mol} / \mathrm{l}\right)$ in the absence or presence of unlabelled porcine insulin (-@), porcine proinsulin $(\mathbf{A}----\mathbf{A})$, guinea pig insulin $(\mathbf{0}-\mathbf{E})$, porcine glucagon $(----X)$ or 1-24 synthetic adrenocorticotropin $(---\square)$. "Total" binding is reported without correction for "non specific". Each point is the mean of triplicate determinations. The results shown are taken from one experiment considered typical of a series of two. The cell concentration was $3 \times 10^{6} \mathrm{cells} / \mathrm{ml}(1 \mathrm{mg}$ cell protein $/ \mathrm{ml}$ )

the presence of unlabelled hormone (Fig. 5). This finding is consistent with the existence of negative cooperativity in the insulin-receptor interactions in our system.

Thus the mixed cell cultures permitted us to demonstrate the existence and to study the properties of the insulin receptor in this system. It became possible, then, to investigate hormone binding in the cloned cell lines. Eleven clones were obtained, which were tentatively classified into three main groups on morphological criteria only. In group I (three clones), the cells were fusiform with two processes, in group II (five clones) polygonal with one long process and in group III (three clones) they were flat and lacked processes. Specific insulin binding could be demonstrated in all the clones (Table 1). Considerable variation in the level of hormone binding was observed with overlapping of the values between the three groups.

\section{Discussion}

Our results demonstrate the existence of insulin binding sites in established permanent cultures of mouse retina cells transformed by Simian virus 40 . In the absence of a known biological effect of the hor-

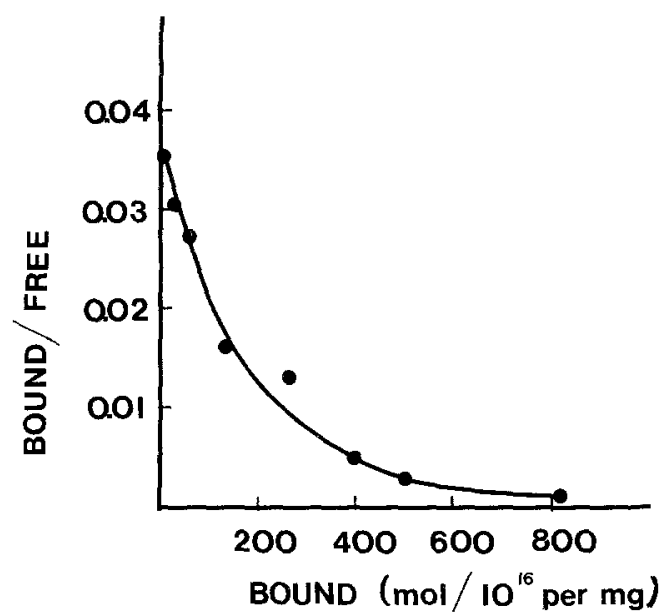

Fig. 4. Scatchard plot of insulin binding to retinal cells. The data are derived from Figure 3, after correction for "non specific" binding

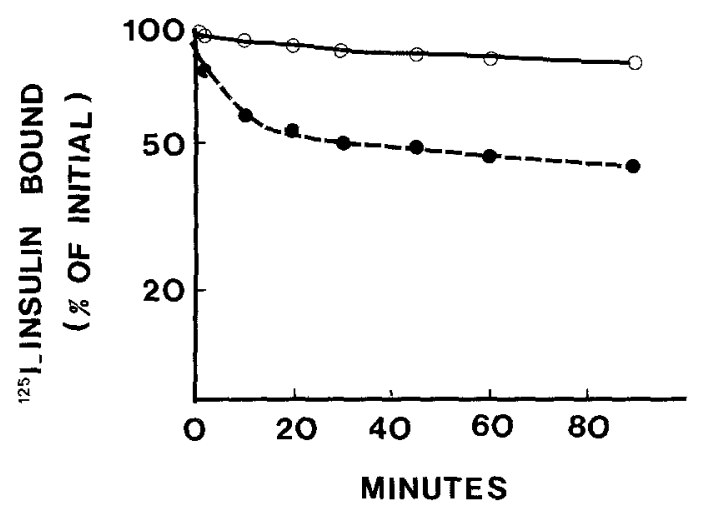

Fig. 5. Dissociation rate of ${ }^{125} \mathrm{I}$-insulin bound to retinal cells. The cells were incubated with ${ }^{125}$ I-insulin $\left(2 \times 10^{-11} \mathrm{~mol} / \mathrm{l}\right)$ for $60 \mathrm{~min}$ at $15^{\circ} \mathrm{C}$. The cell concentration was of $3 \times 10^{6}$ cells $/ \mathrm{ml}$ (or $1 \mathrm{mg}$ cell protein $/ \mathrm{ml}$ ). At 0 time, they were rinsed free of medium, resuspended in buffer without ${ }^{125} \mathrm{I}$-insulin and diluted 100 -fold either in hormone-free medium (open circles) or in medium containing unlabelled insulin $\left(1.7 \times 10^{-7} \mathrm{~mol} / \mathrm{l}\right)$ (closed circles) [22] Each point is the mean of triplicate determinations. The results shown are taken from one experiment considered typical of a series of three

mone, the specificity of these newly described binding sites can be ascertained by comparison of their properties with those of classical target cells. Thus, the insulin receptors on cultured retinal cells were indistinguishable from insulin receptors on numerous other cell types (see 23 for review). Physiological concentrations of unlabelled insulin $\left(2-8 \times 10^{-10}\right.$ $\mathrm{mol} / \mathrm{l}$ ) competed with ${ }^{125}$-I-labelled insulin for binding, and half maximal displacement of labelled insulin was seen at insulin concentrations of about $10 \times$ $10^{-10} \mathrm{~mol} / \mathrm{l}$. The effectiveness of pork proinsulin and guinea pig insulin in competing for insulin binding 
Table 1. ${ }^{125} \mathrm{I}$-insulin binding to the cloned retinal cell lines. The cells were detached from the plates as described in Methods. They were incubated at $15^{\circ} \mathrm{C}$ for $60 \mathrm{~min}$ with ${ }^{125}$ I-insulin $\left(2 \times 10^{-11}\right.$ $\mathrm{mol} / \mathrm{l})$ in the absence or presence of unlabelled insulin $\left(1,7 \times 10^{-6}\right.$ $\mathrm{mol} / \mathrm{l}$ ). The results are expressed as ${ }^{125} \mathrm{I}$-insulin bound (percent of total) per $10^{6}$ cells, after correction for the non-specific binding. The cell concentration was of 2.5 to $4 \times 10^{-6}$ cells $/ \mathrm{ml}$ (or 0.6 to lmg cell protein $/ \mathrm{ml}$, depending on the cell line). The results are the mean of triplicate determinations. Each cell line was tested at least twice

\begin{tabular}{llll}
\hline Cell lines & Cell morphology & clone & $\begin{array}{c}\text { Specific } \\
\text { binding }\end{array}$ \\
\hline Group I & fusiform, & 1 & 0.75 \\
& two processes & 2 & 0.90 \\
Group II & polygonal, & 3 & 0.92 \\
& one process & 2 & 0.33 \\
& & 3 & 0.60 \\
& & 4 & 0.87 \\
Group III & flat, & 5 & 1.00 \\
& no process & 2 & 0.40 \\
& & 3 & 1.12 \\
\hline
\end{tabular}

correlated with the known biological potency of these preparations [23]. In addition, the receptors of the retinal cells showed the characteristic temperature dependence and $\mathrm{pH}$ dependence of binding; association of ${ }^{125} \mathrm{I}$-insulin was more rapid at $37^{\circ} \mathrm{C}$ than at $15^{\circ} \mathrm{C}$, but the steady-state of binding was inversely related to the temperature and was maximal at $\mathrm{pH}$ 7.8. Finally, there was negative cooperativity in the insulin-receptor interaction, as in most of the other insulin receptors [22]. An apparent discrepancy was observed between the very slow dissociation of the tracer after dilution (Fig. 5) and the fact that steadystate of the binding of a non-saturating concentration of ${ }^{125} \mathrm{I}$-insulin was observed after $60 \mathrm{~min}$ (Fig. 1). This may be due to several reasons such as existence of a subpopulation of receptors with a $\mathrm{Kd} \ll 2 \times$ $10^{-11} \mathrm{~mol} / \mathrm{l}$, induction of negative cooperativity by the tracer itself or internalisation of the insulinreceptor complex. A discussion of the kinetics of the insulin binding is beyond the scope of this work [24, $25,26,27]$.

The importance in vivo of the insulin receptor on retinal cells remains to be elucidated. It should be stressed that Havrankova et al. [7] have recently demonstrated the existence of such receptors in homogenates from the retina of adult rats. Thus, the hormone binding that we have investigated in cultured retinal cells exists in the same tissue of living animals. Insulin receptors could also be detected in the three groups of the cloned cell lines, whose different morphology may represent different cell types. Biochemical characterisation of various clones, cur- rently under investigation (B. Pessac, S. Alliot, A. Girard, S. Guérinot, P. Combes, A. Privat, G. Calothy, in preparation), might permit study of the relationships between insulin and specific functions of these cells. It is worth recalling that, in addition to its classical metabolic effects, insulin stimulates $\left(\mathrm{Na}^{+}\right.$ $+\mathrm{K}^{+}$)-dependent ATPase [28] and promotes synthesis of specific membrane phospholipids [29]. These actions may be of special importance in the physiology of neuronal cells.

Acknowledgements. We are grateful to Dr M. H. Laudat for her useful advice, to Mrs F. Alliot for her skilful technical assistance and to Mrs N. Scharapan for the preparation of the manuscript. The study was supported by the I.N.S.E.R.M. grant 77.5.36.4 (C.R.L.).

\section{References}

1. Wurtman, R. J., Fernstrom, J. D.: Control of brain neurotransmitter synthesis by precursor availability and nutritional state. Biochem. Pharmacol. 25, 1691-1696 (1976)

2. Szabo, O., Szabo, A. J.: Studies on the nature and mode of action of the insulin-sensitive glucoregulator receptor in the central nervous system. Diabetes 24, 328-336 (1975)

3. Szabo, A. J., Riederman, R., Szabo, O.: Sensitivity threshold of the glucoregulator insulin receptor in the central nervous system. Fed. Proc. 37, 338 (Abst.) (1978)

4. Woods, S. C., Porte, D., Jr.: Effect of intracisternal insulin on plasma glucose and insulin in the dog. Diabetes 24, 905-909 (1975)

5. Phillips, M. E., Coxon, R. V.: Effect of insulin and phenobarbital on uptake of 2-deoxyglucose by brain slices and hemidiaphragms. J. Neurochem. 27, 643-645 (1976)

6. Posner, B. I., Kelly, P.A., Shiu, R.P.C., Friesen, H. G.: Studies of insulin, growth hormone and prolactin binding: tissue distribution, species variation and characterization. Endocrinology 95, 521-531 (1974)

7. Havrankova, J., Roth, J., Brownstein, M.: Insulin receptors are widely distributed in the central nervous system of the rat. Nature 272, 827-829 (1978)

8. Parks, J. M., Ames, A., III, Nesbett, F. B.: Protein synthesis in central nervous tissue: studies on retina in vitro. J. Neurochem. 27, 987-997 (1976)

9. Vogel, Z., Daniels, M. P., Nirenberg, M.: Synapse and acetylcholine receptor synthesis by neurons dissociated from retina. Proc. Natl. Acad. Sci. USA 73, 2370-2374 (1976)

10. Sarkar, P. K., Lydigsen, J. L.: Hydrocortisone receptors of hormone-responsive and irresponsive embryonic chick retina. Mol. Cell. Endocrinol. 10, 29-38 (1978)

11. Frayser, R., Buse, M. G.: Branched chain amino acid metabolism in the retina of diabetic rats. Diabetologia 14, 171-176 (1978)

12. Pessac, B., Calothy, G.: Transformation of chick embryo neuroretinal cells by Rous sarcoma virus in vitro: induction of cell proliferation. Science 185, 709-710 (1974)

13. Pessac, B., Calothy, G., Alliot, F.: Transformation de cellules retiniennes de souris par le virus Simian 40. CR Acad. Sci. [D] (Paris) 283, 87-88 (1976)

14. Roth, J.: Methods for assessing immunologic and biologic properties of iodinated peptide hormones. In: Methods in Enzymology. Colowick, S. P., Kaplan, N. O. (Ed.), Vol. 37: Peptide Hormones. O'Malley, B. W., Hardman, J. G. (Ed.), pp. 223-233. New York: Academic Press 1975 
15. Thomopoulos, P., Roth, J., Lovelace, E., Pastan, I.: Insulin receptors in normal and transformed fibroblasts: relationship to growth and transformation. Cell 8, 417-423 (1976)

16. Freychet, P., Kahn, C. R., Roth, J., Neville, D. M., Jr.: Insulin interactions with liver plasma membranes: independence of binding of the hormone and its degradation. J. Biol. Chem. 247, 3953-3961 (1972)

17. Neville, D. M., Jr.: Isolation of an organ specific protein antigen from cell-surface membrane of rat liver. Biochim. Biophys. Acta 154, 540-552 (1968)

18. Phillips, H. J.: Dye exclusion tests for cell viability. In: Tissue culture: Methods and Applications. Kruse, Jr., P. F., Patterson, Jr., M. K. (Ed.), pp. 406-408. New York and London: Academic Press 1973

19. Lowry, O. H., Rosebrough, N.H., Farr, A. L., Randall, J.: Protein measurement with the Folin phenol reagent. J. Biol. Chem. 193, 265-275 (1951)

20. Scatchard, G.: The attraction of proteins for small molecules and ions. Ann. N. Y. Acad. Sci. 51, 660-672 (1949)

21. De Meyts, P., Roth, J., Neville, D. M., Jr., Gavin, J. R., III, Lesniac, M. A.: Insulin interactions with its receptors: Experimental evidence for negative cooperativity. Biochem. Biophys, Res. Commun. 55, 154-161 (1973)

22. De Meyts, P., Bianco, A.R., Roth, J.: Site-site interactions among insulin receptors. Characterization of the negative cooperativity. J. Biol. Chem. 251, 1877-1888 (1976)

23. Kahn, C. R.: Membrane receptors for polypeptide hormones. In: Methods in membrane biology. Korn, E. D. (Ed.), Vol. 3, pp. 81-146. New York: Plenum Press 1975
24. De Meyts, P.: Cooperative properties of hormones receptors in cell membranes. J. Supramol. Struct. 4, 241-258 (1976)

25. Schlessinger, J., Schechter, Y., Willingham, M. C., Pastan, I.: Direct visualization of binding, aggregation and internalization of insulin and epidermal growth factor on living fibroblastic cells. Proc. Natl. Acad. Sci. USA 75, 2659-2663 (1978)

26. Kahn, C. R., Baird, K.: The fate of insulin bound to adipocytes. Evidence for compartmentalization and processing. J. Biol. Chem. 253, 4900-4906 (1978)

27. Olefsky, J. M., Chang, H.: Insulin binding to adipocytes. Evidence for functionally distinct receptors. Diabetes 27 , 946-958 (1978)

28. Gavryck, W. A., Moore, R. D., Thompson, R. C.: Effect of insulin upon membrane-bound $\left(\mathrm{Na}^{+}+\mathrm{K}^{+}\right)$-ATPase extracted from frog squeletal muscle. J. Physiol. (Lond.) 252, 43-58 (1975)

29. Mukherjee, S. P., Mukherjee, C., Lynn, W. S.: Insulin-like effects of phosphatidyl inositol on adipocyte plasma membrane functions: glucose metabolism and adenylate cyclase activity. Fed. Proc. 37, 339 (Abst.) (1978)

Received: August 2, 1978

and in revised form: December 6, 1978

Dr. P. Thomopoulos

INSERM U-35

Hôpital Henri Mondor

F-94010 Créteil

France 